\title{
Republicans at odds over human embryo research
} energy and climate issues will play out in the US presidential election. Excerpts:

"The world has made transitions from one type of energy source to another ... in the 75- to 125-year kind of timeframe. We don't have that luxury here. We have to hurry history." Steve Cochran, Environmental Defense Fund, Washington DC

"However you want to cut it - if we're going to get serious about climate-change policy, we're going to have to change the prices of fossil fuels."

Joseph Aldy, fellow, Resources for the Future and co-director of the Harvard Project on International Climate Agreements, Washington DC

"We need... to identify in very concrete terms, not just in a sort of warm and fuzzy way, what new investments in the energy sector mean: where those dollars would go, where those jobs would be created, where an auto worker who is currently making an SUV will now be making a hybrid transmission." Steve Cochran

"If we put too much money into energy $R \& D$ over too short a period of time, there is going to be waste." Richard Newell, professor of energy and environmental economics, Duke University, Durham, North Carolina

"We need to have a diversified portfolio of R\&D [and] we shouldn't pick just one winner. Having said that, let me pick a winner right now ... carbon capture and storage." Joseph Aldy

To hear the full discussion, chaired by our columnist David Goldston (see page 15), visit www.nature.com/nature/podcast. Future podcasts in this series will cover biomedical research and innovation policy.
By changing one little word, the committee drafting the Republican 2008 election platform calls for banning all human embryo research in the United States, whether publicly or privately funded.

John McCain, the presumptive Republican presidential nominee, is under no obligation to follow the party platform - which is a statement of principle with no binding power - but the change highlights the already noticeable contrast between him and the official party position. Although his running mate, Governor Sarah Palin of Alaska, opposes human embryonic stem-cell research, McCain has twice voted to loosen restrictions on federal funding of the work.

On 27 August, the Republican Platform Committee approved an amendment by Mary Summa of

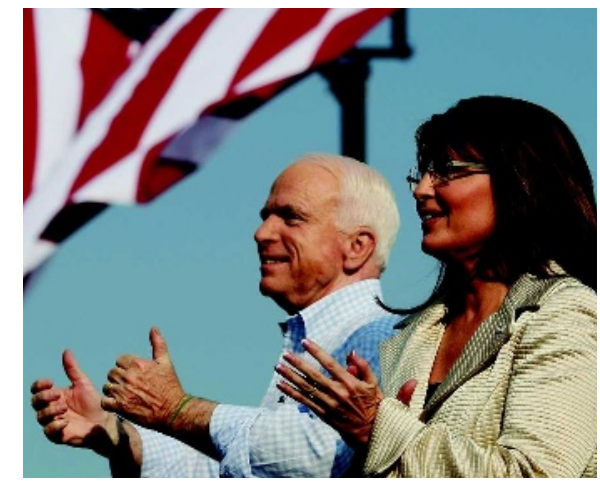

John McCain and running mate Sarah Palin.
Council, a conservative Christian advocacy group in Washington DC, praised the change as "very consistent with the traditional Republican platform that calls for the protection of the dignity of all human life regardless of stage of development".

Even if McCain were to adopt party tenets, the stem-cell restrictions would stand virtually no chance of being enacted by a Democraticled Congress. Still, says Sean Tipton, director of public affairs at the American Society for Reproductive Medicine in Washington DC, "it adds to a chilling effect on the research. Even a whiff of a prohibition of private work just further curtails researchers', investors' and philanthropists' interests."

"I find it almost inconceivable that they would take such a backwards step at North Carolina, one of its 100 or so delegates. It changed "and" to "or" so that the platform now calls for a ban on "the creation of or experimentation on human embryos for research purposes" (emphasis added). The change won final approval during the Republican convention this week in St Paul, Minnesota.

By unlinking the creation of embryos from experimentation on them, the amendment effectively proposes banning a huge swathe of research - from attempts to improve preservation of frozen embryos at in vitro fertilization clinics to the privately financed creation of new stem-cell lines.

The Republican National Committee last week declined to comment on the platform, saying it was not yet official.

The change highlights a rift between social conservatives and Republican moderates such as Michael Castle of Delaware, a Republican member of the House of Representatives and a leading supporter of lifting the funding restrictions. The change, Castle says, "was drafted by people who don't even understand the advances that have been made in embryonic stem-cell research and its future potential".

But David Christensen, the leading lobbyist on embryo-related issues at the Family Research this point in time," adds Peter Mathers, who chairs the stem-cell subcommittee of the science-policy committee for the Federation of American Societies for Experimental Biology. "Remaining neutral is one thing. Going backwards seems to be very disconcerting."

Barack Obama, the Democratic nominee for president, has, like McCain, voted to lift federal funding restrictions on stem-cell research. Last week, the science advocacy group Science Debate 2008 released answers from Obama on several science-related topics, including a statement on stem-cell research that he favours "responsible oversight of it, in accord with recent reports from the National Research Council”.

As with stem-cell research, McCain and his party also diverge on climate change. The proposed platform cautions against "doomsday climate-change scenarios peddled by the aficionados of centralized command-and-control government". Echoing the 2004 platform, it advocates "technology-driven, market-based solutions" to increased atmospheric carbon.

McCain, in contrast, has promised to enact mandatory limits on greenhouse-gas emissions through a cap-and-trade system.

Meredith Wadman 